\title{
THE EUROPEAN UNION AND THE UNITED KINGDOM: NEW LEGAL FRAMEWORK FOR COOPERATION
}

\author{
Dmitry V. Galushko \\ Financial University under the Government of the Russian Federation, Moscow, Russian Federation
}

\begin{abstract}
Introduction: the paper analyzes the main stages of the negotiation process between the European Union and the United Kingdom on the issue of concluding a basic agreement regulating the future relations of the two parties in various areas of cooperation. The purpose of the study is to study and analyze the political and legal aspects of the negotiation process for the conclusion of the EU-UK Trade and Cooperation Agreement, the content of its main provisions, and the impact on the future framework of relations between the parties. Methods: in the course of the study, both general scientific methods of cognition and private legal methods (formal-legal, historicallegal) were used. Results: the paper proves that, despite all the difficulties that arose during the negotiation process throughout 2020, the parties managed to overcome numerous differences and conclude a basic agreement that outlined the future framework of relations between the EU and the UK. Conclusions: the analysis showed that the Agreement on Trade and Cooperation between the EU and the UK is unlikely to be the endpoint of the Brexit process. Although the Agreement establishes a framework for interaction on many issues, however, the parties are expected to continue to review and adjust the legal framework of the relationship, since, on the one hand, it is possible to supplement the Agreement on Trade and Cooperation with other treaties to regulate other areas of crucial importance for the parties that are not covered by the document, and on the other hand, also concerning some issues that, although settled, will soon require additional legal regulation, which indicates that the historic Brexit process is far from complete.
\end{abstract}

Key words: European Union, United Kingdom, Brexit, Agreement on Trade and Cooperation, interaction, trade, cooperation.

Citation. Galushko D.V. The European Union and the United Kingdom: New Legal Framework for Cooperation. Legal Concept = Pravovaya paradigma, 2021, vol. 20, no. 3, pp. 176-183. (in Russian). DOI: https://doi.org/10.15688/lc.jvolsu.2021.3.26

УДК $341.1 / 8$

ББК 67.9

Дата поступления статьи: 08.05.2021 Дата принятия статьи: 14.06 .2021

\section{ЕВРОПЕЙСКИЙ СОЮЗ И ВЕЛИКОБРИТАНИЯ:} НОВЫЕ ПРАВОВЫЕ РАМКИ СОТРУДНИЧЕСТВА

\footnotetext{
Дмитрий Вячеславович Галушко

Финансовый университет при Правительстве Российской Федерации, г. Москва, Российская Федерация

Введение: в статье анализируются основные этапы переговорного процесса между Европейским союзом и Великобританией по вопросу заключения базового соглашения, регулирующего будущие взаимоот-
} 
ношения двух сторон в различных областях сотрудничества. Цель исследования заключается в исследовании и анализе политико-правовых аспектов переговорного процесса по заключению Соглашения о торговле и сотрудничеству ЕС и Великобритании, содержания его основных положений и влияния на будущие рамки взаимоотношений сторон. Методы: в ходе исследования использовались как общенаучные методы познания, так и частноправовые методы (формально-юридический, историко-правовой). Результаты: в статье обосновано, что, несмотря на все сложности, возникшие в ходе переговорного процесса в течение всего 2020 г., стороны сумели преодолеть многочисленные разногласия и заключить базовое соглашение, очертившее будущие рамки взаимоотношений ЕС и Великобритании. Выводы: проведенный анализ показал, что Соглашение о торговле и сотрудничестве между ЕС и Великобританией вряд ли станет конечной точкой процесса Брекзита. Хотя Соглашение и устанавливает рамки взаимодействия по целому ряду вопросов, однако, как ожидается, стороны будут продолжать пересматривать и корректировать правовую основу взаимоотношений, так как, с одной стороны, оставлена возможность дополнить Соглашение о торговле и сотрудничестве другими договорами для регулирования иных имеющих важнейшее значение для сторон сфер, документом не охваченных, а с другой стороны, также в отношении некоторых вопросов, которые хотя и урегулированы, в скором времени потребуют дополнительной правовой регламентации, что говорит о том, что исторический процесс Брекзита еще далек от своего полного завершения.

Ключевые слова: Европейский союз, Великобритания, Брекзит, Соглашение о торговле и сотрудничеству, взаимодействие, торговля, сотрудничество.

Цитирование. Галушко Д. В. Европейский союз и Великобритания: новые правовые рамки сотрудничества // Legal Concept = Правовая парадигма. -2021.-T. 20, №3. -C. 176-183.-DOI: https://doi.org/10.15688/lc.jvolsu.2021.3.26

\section{Введение}

После официального выхода Великобритании из Европейского союза 31 января 2020 г. ст. 126 Договора о выходе предполагался переходный период, который продлился до 31 декабря 2020 г. [1]. Он мог быть продлен на один или два года по взаимному согласию сторон не позднее 1 июля 2020 года. Предполагалось, что данный период обеспечит мягкий переход Британии из отношений как государства - члена ЕС к отношениям как с третьей страной. Переходный период был необходим, чтобы Великобритания и Европейский союз подписали новое соглашение об условиях торговли, когда Британия покинет таможенный союз и общий рынок. Если бы такое соглашение об установлении будущего партнерства между Великобританией и Европейским союзом не было бы принято, то после переходного периода с 1 января 2021 г. Соединенное Королевство осуществляло бы торговлю с ЕС на условиях Всемирной торговой организации (ВТО).

Разработка и принятие международного договора о будущих взаимоотношениях между Европейским союзом и Великобританией ознаменовало начало новой эпохи как в развитии Соединенного Королевства, так и европейского интеграционного образования. В рамках настоящей статьи мы рассмотрим неко- торые правовые и политические аспекты переговорного процесса по заключению соглашения о будущих взаимоотношениях ЕС и Великобритании, повлиявшие на его исход, после формального выхода этого государства из ЕС для обеспечения упорядоченного перехода к новым рамкам сотрудничества.

\section{Политико-правовые аспекты переговорного процесса}

3 февраля 2020 г. Европейская комиссия приняла рекомендации для Европейского совета о начале переговоров с Соединенным Королевством о дальнейшем партнерстве. По мнению Еврокомиссии, процесс должен включать три основных компонента: общие договоренности (в том числе положения об основных ценностях и принципах, а также управлении); экономические договоренности (в частности, положения о торговле и равных гарантиях); договоренности по вопросам безопасности (в том числе положения о правоприменении и правовом сотрудничестве по уголовным делам, а также по внешней политике, безопасности и обороне) [14]. Премьер-министр Великобритании Борис Джонсон в тот же день опубликовал письменное обращение в парламент «Будущие отношения между Соединенным Королевством и Европейским Союзом», фокусируясь на аспектах торговли [15]. 


\section{МЕЖДУНАРОДНОЕ ПРАВО И СРАВНИТЕЛЬНОЕ ПРАВОВЕДЕНИЕ}

Основными вопросами для обсуждения с обеих сторон стали условия будущей торговли товарами и услугами, рыболовство, миграция, вопросы внешней политики, внутренних дел и обеспечения безопасности. И Великобритания, и ЕС изначально соглашались, что ключевой целью должна стать отмена тарифов и квот, высказывая намерение сотрудничать для минимизации регуляторных барьеров.

Совет принял решение, разрешающее начало переговоров, 25 февраля 2020 г. [5]. Первый раунд переговоров начался 2 марта 2020 года. Их вели Мишель Барнье от имени ЕС и Дэвид Фрост от имени Великобритании. В феврале 2020 г. ЕС и Великобритания объявили о своих подходах и целях к переговорам. Подход Великобритании [16] отличался от положений в принятой Политической декларации, поскольку она закрепляла принятие отдельных соглашений в соответствующих областях. Напротив, директивы Совета для переговоров поддерживали подход к достижению единого всеобъемлющего соглашения [3]. Для ЕС подписание большого количества отдельных соглашений привело бы к увеличению институционального механизма, который контролировал бы реализацию каждого из них. Кроме того, области, которые были предметом двусторонних переговоров, являлись взаимосвязанными, вызывая необходимость комплексного подхода и позволяя при необходимости межотраслевое взаимодействие.

В период с марта по октябрь 2020 г. было проведено девять раундов переговоров, охватывающих одиннадцать сфер будущего сотрудничества сторон. Европейская комиссия от имени ЕС и Великобритания опубликовали свои предложения по тексту переговоров соответственно в марте и мае 2020 года. Правительство Великобритании опубликовало девять проектов документов, касающихся всех областей будущих взаимоотношений с Европейским союзом [13], среди которых Всеобъемлющее соглашение о свободной торговле (CFTA) [9] и Рамочное соглашение о рыболовстве [10]. В свою очередь, ЕС выпустил проект единого документа, озаглавленный «Соглашение о Новом партнерстве с Соединенным Королевством» (ANP) [8]. В июне 2020 г., несмотря на остающиеся расхожде- ния в позициях по основным направлениям, Beликобритания отказалась рассматривать продление переходного периода, возможного в рамках Соглашения о выходе, заявив, что переходный период в любом случае истечет 31 декабря 2020 года. В связи с этим стороны активизировали переговоры, в частности, проводя ежедневные переговоры в декабре 2020 г., стремясь преодолеть имеющиеся разногласия.

В итоге, после более чем десяти месяцев переговоров буквально перед Рождеством, 24 декабря 2020 г., Европейская комиссия от имени Европейского союза и Соединенное Королевство достигли соглашения об условиях их будущих отношений. 29 декабря 2020 г. Совет ЕС принял решение о подписании Соглашения о торговле и сотрудничестве между ЕС и Великобританией и его временном применении с 1 января 2021 года. Президент Европейского Совета Шарль Мишель и Президент Европейской Комиссии Урсула фон дер Ляйен подписали соглашение от имени ЕС, а премьер-министр Борис Джонсон - от имени Великобритании 30 декабря 2020 года.

\section{Соглашение о торговле и сотрудничестве между Великобританией и ЕС: основные положения}

Соглашение о торговле и сотрудничестве состоит из семи частей, две из которых включают общие и финальные положения, а также «горизонтальные» положения, то есть институциональную основу и механизм урегулирования споров, четыре части относятся к конкретным областям сотрудничества (торговля, транспорт, рыболовство, а также сотрудничество между правоохранительными и судебными органами по уголовным делам).

Возможность временного применения международного договора в соответствии с законодательством ЕС изложена в ст. 218 (5) Договора о функционировании ЕС, и решение о временном применении может быть принято «при необходимости» до того момента, как Европейский Парламент его одобрит [2]. Однако, в соответствии со ст. 218 (6) ДФЕС Совет может принять решение о заключении соглашения только после получения согласия Парламента. Такое согласие было получено 
28 апреля 2021 г. с принятием соответствующей резолюции [11]. Парламент Великобритании принял ратификационный акт гораздо раньше: Акт о Европейском союзе (будущих отношениях) [12] для ратификации данного Соглашения и введения его в действие во внутреннем праве страны был одобрен практически сразу же после заключения Соглашения.

Со стороны Европейского союза некоторые положения о реализации были изначально установлены в решении Совета ЕС о подписании Соглашения [6]. Соглашение заключается только между Великобританией и ЕС, иными словами, не между третьей страной, не входящей в ЕС, с одной стороны, и Европейским союзом и его государствами-членами - с другой, как это часто бывает в практике ЕС. Данный аспект впоследствии подчеркивался в заявлениях некоторых институтов ЕС и государств-членов о подписании договора [4], который по своей сущности и юридическим признакам является «соглашением об ассоциации» со стороны ЕС, несмотря на его название. В дополнение к Соглашению имеется целый ряд совместных деклараций [7].

Любая из сторон может направить уведомление о расторжении соглашения, после чего оно прекратит свое действие спустя 12 месяцев. Кроме того, закреплен целый ряд положений о возможности прекращения или приостановления действия определенных частей данного международного договора, что отличает его от Соглашения о выходе, которое не содержит положения о прекращении действия всего договора, а содержит только положения о прекращении действия протокола по Северной Ирландии.

Соглашение также предусматривает, что с Великобританией будут проводиться консультации по вопросам вступления в ЕС новых стран. Однако данная процедура не предусматривает возможности каким-либо образом государству воспрепятствовать данному процессу. Представляется, что потенциально Великобритания не сможет, например, помешать присоединению Шотландии к ЕС, используя данную международную процедуру. В соглашение могут быть внесены поправки в свете будущих расширений ЕС, как это также происходит с другими международными до- говорами ЕС со странами, не входящими в ЕС, когда новое государство-член присоединяется к организации. При этом не установлено никаких положений о том, что произойдет, если еще больше стран покинет ЕС, если Великобритания распадется или если произойдет и то и другое.

Что касается территориальной сферы действия Соглашения, то оно распространяется на Нормандские острова и остров Мэн. Однако не закреплено никаких положений о заморских территориях Великобритании, а статус Гибралтара будет урегулирован отдельным международным договором.

Большая часть Соглашения состоит из разделов, касающихся экономического сотрудничества. Прежде всего, они предусматривают, что торговля товарами будет происходить на условиях нулевых тарифов и квот. Тем не менее в отдельных случаях стороны могут вводить нетарифные барьеры, в частности специальные правила в отношении происхождения товаров. Что касается цифровой торговли, то нормы Соглашения гарантируют верховенство правил защиты персональных данных и конфиденциальности, а также предусматривают запрет на введение таможенных пошлин в сфере электронных транзакций, а также на требования по локализации данных. Положения, касающиеся вопросов регулирования энергетического сектора, устанавливают предоставление доступа к оптовым рынкам и обеспечивают основу для разработки правил управления межсистемными подключениями электроэнергии и газа; ключевые принципы права ЕС, касающиеся сферы энергетики, будут продолжать применяться к отношениям сторон. В сферах воздушного и автомобильного транспорта Соглашение позволяет операторам предоставлять услуги из пунктов, находящихся на территории ЕС, в пункты на территории Великобритании и наоборот. Что касается миграционных вопросов, то нормы Соглашения закрепляют безвизовый режим для краткосрочного туризма, в частности перемещения в деловых целях. Также предусматривается координация вопросов социального обеспечения. В отношении сферы рыболовства - постепенный перенос квот на вылов от ЕС к Великобритании, что составляет четверть объема вылова ЕС в водах 


\section{МЕЖДУНАРОДНОЕ ПРАВО И СРАВНИТЕЛЬНОЕ ПРАВОВЕДЕНИЕ}

Великобритании, после чего они могут быть изменены только по взаимному согласию. Кроме того, Соглашение предусматривает компенсационные меры в случае сокращения доступа к водным ресурсам, например, посредством роста тарифов.

В соответствующей части Соглашения предусматривается постоянное сотрудничество в правоохранительной и судебной сферах по уголовным делам. Среди прочего предусматривается обмен данными между сторонами (однако без предоставления Великобритании прямого доступа к базам данных и информационным системам ЕС), а также вводится новый механизм выдачи лиц, обвиняемых или осужденных за преступления. Великобритания также продолжит сотрудничество с агентствами ЕС, компетентными в данной области (Европолом и Евроюстом) в рамках модели сотрудничества с третьими странами. Соглашение также устанавливает общие принципы участия Великобритании в различных программах ЕC.

Основным компонентом управленческого механизма в отношении Соглашения является Совет партнерства, сопредседатели которого - назначенные члены Европейской Комиссии и правительства Великобритании. Всесторонне содействие деятельности Совета будут осуществлять девятнадцать специализированных комитетов. Предполагается, что Совет будет следить за достижением целей Соглашения, а также контролировать его выполнение и применение.

Кроме того, Соглашение предусматривает целый ряд общих и специализированных механизмов урегулирования споров. Несмотря на то что изначально ЕС высказывал мнение о необходимости сохранения за Судом ЕС его роли в решении любых споров, которые могут возникнуть в ходе торговли между Великобританией и ЕС, итоговый вариант данного международного договора никоим образом не подпадает под юрисдикцию Суда ЕС. В частности, п. 3 ст. COMPROV.13 специально исключает юрисдикцию Суда ЕС: «Для большей уверенности толкование настоящего Соглашения или любого дополнительного соглашения, вынесенного судами любой из Сторон, не будет иметь обязательной силы для судов другой Стороны» [17].

\section{Выводы}

Соглашение о торговле и сотрудничестве между ЕС и Великобританией во многом устанавливает правовые рамки будущих отношений между ЕС и Великобританией. В связи с тем, что Договор о выходе регулировал лишь общие условия отделения Великобритании от EC, необходимы были новые механизмы формализации условий нового сотрудничества, охватывающие значительную часть всего спектра взаимоотношений. Процесс формализации будущих отношений между ЕС и Великобританией растянулся почти на весь 2020 год, столкнувшись с беспрецедентными проблемами - не в последнюю очередь из-за вспышки пандемии COVID-19. На определенных этапах переговоры между ЕС и Великобританией были на грани срыва, тем не менее экзогенные и эндогенные факторы в конечном итоге подтолкнули стороны к тому, чтобы избежать разрыва, и всего за неделю до окончания переходного периода они достигли принципиальной договоренности по Соглашению о торговле и сотрудничестве.

Тем не менее, как показал проведенный анализ, Соглашение о торговле и сотрудничестве между ЕС и Великобританией вряд ли станет конечной точкой процесса Brexit. Хотя Соглашение и устанавливает рамки, в которых ЕС и Великобритания, однако, как ожидается, стороны будут продолжать пересматривать и корректировать свои взаимоотношения: это вытекает не только из договорного обязательства о возможности пересмотра документа и других дополняющих его соглашений каждые пять лет, но и из множества других норм, содержащихся в различных разделах документа, которые предусматривают продолжение переговоров между сторонами, в частности, относительно ежегодных квот на вылов рыбы. Фактически ЕС и Великобритания также оставляют за собой возможность дополнить Соглашение о торговле и сотрудничестве другими договорами - для регулирования иных имеющих важнейшее значение для сторон сфер, например сектора финансовых услуг, вопросов внешней политики, иными словами, сфер, которые в настоящее время не охвачены новым соглашением между $\mathrm{EC}$ и Великобританией. Кроме того, так как 
Соглашение устанавливает в отношении некоторых вопросов дополнительные переходные режимы, например, в отношении трансграничной передачи персональных данных, можно предположить, что соответствующая правовая база будет развиваться и дополняться в последующем, что говорит о том, что исторический процесс Brexit еще далек от своего полного завершения.

\section{СПИСОК ЛИТЕРАТУРЫ}

1. Agreement of the Withdrawal of the United Kingdom of Great Britain and Northern Ireland from the European Union and the European Atomic Energy Community // Official Journal. - 2020. - Jan. 19. L. 29. - P. 7-18.

2. A Guide to EU Procedures for the Conclusion of International Trade Agreements. - Electronic text data. Mode of access: https://www.europarl.europa.eu/ RegData/etudes/BRIE/2016/593489/EPRS_BRI(2016) 593489_EN.pdf(date of access: 05.05.2021). - Title from screen.

3. Annex to Council Decision Authorising the Opening of Negotiations with the United Kingdom of Great Britain and Northern Ireland for a New Partnership Agreement. - Electronic text data. - Mode of access: https://www.consilium.europa.eu/media/ 42736/st05870-ad01re03-en20.pdf (date of access: 05.05.2021). - Title from screen.

4. Communication of Council of the European Union. - Electronic text data. - Mode of access: https://data.consilium.europa.eu/doc/document/ CM-5525-2020-INIT/en/pdf (date of access: 05.05.2021). - Title from screen.

5. Council Decision Authorising the Opening of Negotiations with the United Kingdom of Great Britain and Northern Ireland for a New Partnership Agreement. - Electronic text data. - Mode of access: https://www.consilium.europa.eu/media/42737/ st05870-en20.pdf (date of access: 05.05.2021). - Title from screen.

6. Council Decision (EU) 2020/2252 of 29 December 2020 on the Signing, on Behalf of the Union, and on Provisional Application of the Trade and Cooperation Agreement Between the European Union and the European Atomic Energy Community, of the One Part, and the United Kingdom of Great Britain and Northern Ireland, of the Other Part, and of the Agreement Between the European Union and the United Kingdom of Great Britain and Northern Ireland Concerning Security Procedures for Exchanging and Protecting Classified Information // Official Journal. 2020. - Dec. 31. - L. 444. - P. 2-10.
7. Declarations Referred to in the Council Decision on the Signing on Behalf of the Union, and on a Provisional Application of the Trade and Cooperation Agreement and of the Agreement Concerning Security Procedures for Exchanging and Protecting Classified Information // Official Journal. 2020. - Dec. 31. - L. 444. - P. 1475-1485.

8. Draft Text of the Agreement on the New Partnership with the United Kingdom. - Electronic text data. - Mode of access: https://ec.europa.eu/info/ sites/info/files/200318-draft-agreement-gen.pdf(date of access: 05.05.2021). - Title from screen.

9. Draft Working Text for a Comprehensive Free Trade Agreement Between the United Kingdom and the European Union. - Electronic text data. - Mode of access: https://assets.publishing.service.gov.uk/ government/uploads/system/uploads/attachment data/file/886010/DRAFT_UK-EU_Comprehensive_ Free_Trade_Agreement.pdf (date of access: 05.05.2021). - Title from screen.

10. Draft Working Text for a Fisheries Framework Agreement Between the United Kingdom of Great Britain and Northern Ireland and the European Union. - Electronic text data. - Mode of access: https://assets.publishing.service.gov.uk/government/ uploads/system/uploads/attachment_data/file/886009 /DRAFT_Fisheries_Framework_Agreement.pdf(date of access: 05.05.2021). - Title from screen.

11. European Parliament Legislative Resolution of 28 April 2021 on the Draft Council Decision on the Conclusion, on Behalf of the Union, of the Trade and Cooperation Agreement Between the European Union and the European Atomic Energy Community, of the One Part, and the United Kingdom of Great Britain and Northern Ireland, of the Other Part, and of the Agreement Between the European Union and the United Kingdom of Great Britain and Northern Ireland Concerning Security Procedures for Exchanging and Protecting Classified Information (05022/2021 - C90086/ 2021 - 2020/0382(NLE)). - Electronic text data. - Mode of access: https://www.europarl.europa.eu/doceo/ document/TA-9-2021-0140_EN.html (date of access: 05.05.2021). - Title from screen.

12. European Union (Future Relationship) Act 2020. - Electronic text data. - Mode of access: https://www.legislation.gov.uk/ukpga/2020/29/pdfs/ ukpga_20200029_en.pdf(date of access: 05.05.2021). Title from screen.

13. Policy Paper «Our Approach to the Future Relationship with the EU». - Electronic text data. Mode of access: https://www.gov.uk/government/ publications/our-approach-to-the-future-relationshipwith-the-eu (date of access: 05.05.2021). - Title from screen.

14. Recommendation for a Council Decision Authorising the Opening of Negotiations for a New 


\section{МЕЖДУНАРОДНОЕ ПРАВО И СРАВНИТЕЛЬНОЕ ПРАВОВЕДЕНИЕ}

partnership with the United Kingdom of Great Britain and Northern Ireland. - Electronic text data. - Mode of access: https://eur-lex.europa.eu/legal-content/en/ ALL/?uri=CELEX:52020PC0035 (date of access: 05.05.2021). - Title from screen.

15. The Future Relationship between the UK and the EU : Written Statement to Parliament. - Electronic text data. - Mode of access: https:/www.gov.uk/ government/speeches/the-future-relationshipbetween-the-uk-and-the-eu (date of access: 05.05.2021). - Title from screen.

16. The Future Relationship with the EU: The UK's Approach to Negotiations. - Electronic text data. - Mode of access: https://assets.publishing.service.gov.uk/ government/uploads/system/uploads/attachment data/ file/868874/The Future Relationship_with the EU.pdf(date of access: 05.05.2021). - Title from screen.

17. Trade and Cooperation Agreement Between the European Union and the European Atomic Energy Community, of the One Part, and the United Kingdom of Great Britain and Northern Ireland, of the Other Part // Official Journal. - 2020. - Dec. 31. - L. 444. - 1246 p.

\section{REFERENCES}

1. Agreement of the Withdrawal of the United Kingdom of Great Britain and Northern Ireland from the European Union and the European Atomic Energy Community. Official Journal, 2020, Jan. 31, 1. 29, pp. 7-18.

2. A Guide to EU Procedures for the Conclusion of International Trade Agreements. URL: https:// www.europarl.europa.eu/RegData/etudes/BRIE/2016/ 593489/EPRS_BRI(2016)593489_EN.pdf (accessed 5 May 2021).

3. Annex to Council Decision Authorising the Opening of Negotiations with the United Kingdom of Great Britain and Northern Ireland for a New Partnership Agreement. URL: https://www.consilium. europa.eu/media/42736/st05870-ad01re03-en20.pdf (accessed 5 May 2021).

4. Communication of Council of the European Union. URL: https://data.consilium.europa.eu/doc/ document/CM-5525-2020-INIT/en/pdf (accessed 5 May 2021).

5. Council Decision Authorising the Opening of Negotiations with the United Kingdom of Great Britain and Northern Ireland for a New Partnership Agreement. URL: https://www.consilium.europa.eu/ media/42737/st05870-en20.pdf(accessed 5 May 2021).

6. Council Decision (EU) 2020/2252 of 29 December 2020 on the Signing, on Behalf of the Union, and on Provisional Application of the Trade and Cooperation Agreement Between the European Union and the European Atomic Energy Community, of the One Part, and the United Kingdom of Great Britain and Northern Ireland, of the Other Part, and of the Agreement Between the European Union and the United Kingdom of Great Britain and Northern Ireland Concerning Security Procedures for Exchanging and Protecting Classified Information. Official Journal, 2020, Dec. 31, 1. 444, pp. 2-10.

7. Declarations Referred to in the Council Decision on the Signing on Behalf of the Union, and on a Provisional Application of the Trade and Cooperation Agreement and of the Agreement Concerning Security Procedures for Exchanging and Protecting Classified Information. Official Journal, 2020, Dec. 31, 1. 444, pp. 1475-1485.

8. Draft Text of the Agreement on the New Partnership with the United Kingdom. URL: https:// ec.europa.eu/info/sites/info/files/200318-draftagreement-gen.pdf(accessed 5 May 2021).

9. Draft Working Text for a Comprehensive Free Trade Agreement Between the United Kingdom and the European Union. URL: https://assets.publishing. service.gov.uk/government/uploads/system/uploads/ attachment_data/file/886010/DRAFT_UK-EU_ Comprehensive_Free_Trade_Agreement.pdf (accessed 5 May 2021).

10. Draft Working Text for a Fisheries Framework Agreement Between the United Kingdom of Great Britain and Northern Ireland and the European Union. URL: https://assets.publishing.service.gov.uk/ government/uploads/system/uploads/attachment_ data/file/886009/DRAFT_Fisheries_Framework_ Agreement.pdf(accessed 5 May 2021).

11. European Parliament Legislative Resolution of 28 April 2021 on the Draft Council Decision on the Conclusion, on Behalf of the Union, of the Trade and Cooperation Agreement Between the European Union and the European Atomic Energy Community, of the one Part, and the United Kingdom of Great Britain and Northern Ireland, of the Other Part, and of the Agreement Between the European Union and the United Kingdom of Great Britain and Northern Ireland Concerning Security Procedures for Exchanging and Protecting Classified Information (05022/2021 C90086/2021 - 2020/0382(NLE)). URL: https:// www.europarl.europa.eu/doceo/document/TA-9-20210140_EN.html (accessed 5 May 2021).

12. European Union (Future Relationship) Act 2020. URL: https:/www.legislation.gov.uk/ukpga/2020/ 29/pdfs/ukpga_20200029_en.pdf(accessed 5 May2021).

13. Policy paper "Our approach to the Future Relationship with the EU”. URL: https://www.gov.uk/ government/publications/our-approach-to-the-futurerelationship-with-the-eu (accessed 5 May 2021).

14. Recommendation for a Council Decision authorising the opening of negotiations for a new partnership with the United Kingdom of Great Britain 
and Northern Ireland. URL: https://eur-lex.europa.eu/ legal-content/en/ALL/?uri=CELEX:52020PC0035 (accessed 5 May 2021).

15. The Future Relationship between the UK and the EU: Written statement to Parliament. URL: https://www.gov.uk/government/speeches/the-futurerelationship-between-the-uk-and-the-eu (accessed 5 May 2021).

16. The Future Relationship with the EU: The UK's Approach to Negotiations. URL: https:// assets.publishing.service.gov.uk/government/ uploads/system/uploads/attachment_data/file/ 868874/The_Future_Relationship_with_the_EU.pdf (accessed 5 May 2021).

17. Trade and cooperation agreement between the European Union and the European Atomic Energy Community, of the one part, and the United Kingdom of Great Britain and Northern Ireland, of the other part. Official Journal, 2020, 1. 444, Dec. 31, pp. 14-1462.

\section{Information About the Author}

Dmitry V. Galushko, Candidate of Sciences (Jurisprudence), Associate Professor, Department of Legal Regulation of Economic Operations, Financial University under the Government of the Russian Federation, Prosp. Leningradsky, 49, 125993 Moscow, Russian Federation, galushkodv@gmail.com, https://orcid.org/0000-0002-9301-9565

\section{Информация об авторе}

Дмитрий Вячеславович Галушко, кандидат юридических наук, доцент Департамента правового регулирования экономической деятельности, Финансовый университет при Правительстве Российской Федерации, просп. Ленинградский, 49, 125993 г. Москва, Российская Федерация, galushkodv@gmail.com, https://orcid.org/0000-0002-9301-9565 